\begin{tabular}{|c|c|c|}
\hline \multirow{3}{*}{ IDUNAS } & NATURAL \& APPLIED SCIENCES & 2020 \\
& JOURNAL & No.2 \\
$(64-70)$
\end{tabular}

\title{
Biogas Potentials of Anaerobic Co-Digestion of Rumen Contents and Sewage Sludge
}

\author{
Research Article \\ Francis James OGBOZIGE ${ }^{1 *(D)}$, Tanimu Shamsudeen USMAN $^{2}$ iD, Umar Alfa ABUBAKAR ${ }^{3}$ (D) \\ ${ }^{l}$ Department of Civil Engineering, Federal University Otuoke, Nigeria \\ ${ }^{2}$ Depatment of Water Resources \& Environmental Engineering, Ahmadu Bello University, Zaria, Nigeria \\ ${ }^{3}$ Depatment of Water Resources \& Environmental Engineering, Ahmadu Bello University, Zaria, Nigeria \\ *Correspondance to: Francis James Ogbozige, Department of Civil Engineering, Federal University Otuoke, Nigeria
}

Author E-mails

engr.ogbozige@gmail.com

DOI: $10.38061 /$ idunas. 819080

Received:31.10.2020; Accepted:11.12.2020

\section{Abstract}

Sewage sludge (SS) and rumen contents (RC) are produced daily in waste stabilization ponds and abattoirs respectively as organic wastes. However, these wastes could pose a threat to the environment if not properly managed hence, this research investigated the potentials of these wastes in generating biogas. This was achieved by digesting different SS/RC ratios anaerobically for 75days and recording the biogas produced under mesophilic condition. The SS and RC were obtained from Ahmadu Bello University (ABU) waste stabilization pond and cattle (Bos indicus) respectively, while the SS/RC ratios considered are 1:0, 0:1, 1:1, 1:2 and 2:1. Results showed that co-digestion at SS/RC ratios 1:1, 1:2 and 2:1 produced more biogas compared to mono-digestions of equivalent volumes of SS (1:0) and RC (0:1). This is because the daily biogas potentials for SS/RC ratios 1:0, 0:1, 1:1, 1:2 and 2:1 are 3.59, 5.61, 6.09, 6.67 and 5.79ml per gram of TS added respective. In other words, biogas potential for SS improved by 69.64, 85.79 and 61.28\% when co-digested with $\mathrm{RC}$ at $\mathrm{SS} / \mathrm{RC}$ ratios $1: 1,1: 2$ and 2:1 respectively, while that of RC improved by 8.56 , 18.89 and $3.21 \%$ at $\mathrm{SS} / \mathrm{RC}$ ratios 1:1, 1:2 and 2:1 respective. Hence, it was concluded that co-digestion of $\mathrm{SS}$ and $\mathrm{RC}$ at $\mathrm{SS} / \mathrm{RC}$ ratio $1: 2$ produced more biogas followed by 1:1 and 2:1 accordingly.

Keywords: Biogas, Mesophilic, Rumen, Sludge. 


\section{INTRODUCTION}

The discharge of untreated sewage into the environment could cause a lot of adverse effects on human health since sewage usually contains numerous life threatening pathogens including Vibrio cholerae and Salmonella typhi. It could also lead to eutrophication of streams and rivers with its associated effects. Hence, in 1979, the management of Ahmadu Bello University (ABU), Zaria-Nigeria decided to design and construct a Waste Stabilization Pond (WSP) that could treat the wastewater generated within the university community before discharging to the nearby Kubani stream. However, during the operation of a WSP, sludges are frequently formed as byproduct and needs to be removed periodically in order not to reduce the volume and treatment efficiency of the pond thus, increasing the operating cost of WSP. Zaria, been the host community of Ahmadu Bello University is known to have numerous abattoirs especially for the ruminants. Usually, the ingesta (rumen contents) in these abattoirs are disposed by merely dumping on the ground surface until they accumulate to form heaps, allowed to dry and then burnt openly. This is not environmentally friendly because rumen contents contain so much bacteria [1-3]. Hence, if disposed in this manner, the watery component could leached into the ground to contaminate groundwater. In addition, the open burning of these dried heaps of rumen contents pollutes the atmosphere.

Global warming is one of the main environmental problems disturbing the world however, researchers have shown that the use of renewable energy at homes, institutions and industries could reduce its effects considerably $[4,5]$. Biogas has been identified for long as one the sources of renewable energy and it is generated when bacteria decompose organic materials in the absence of oxygen to produce mostly methane and carbon dioxide in a process known as anaerobic digestion [6-7]. The gas produced usually consist of $55-75 \%$ methane and $25-45 \%$ carbon dioxide with trace amount of other gases especially nitrogen [8]. However, the anaerobic digestion (AD) comprises four stages known as hydrolysis, acidogenesis, acetogenesis and methanogenesis as shown in Figure 1.

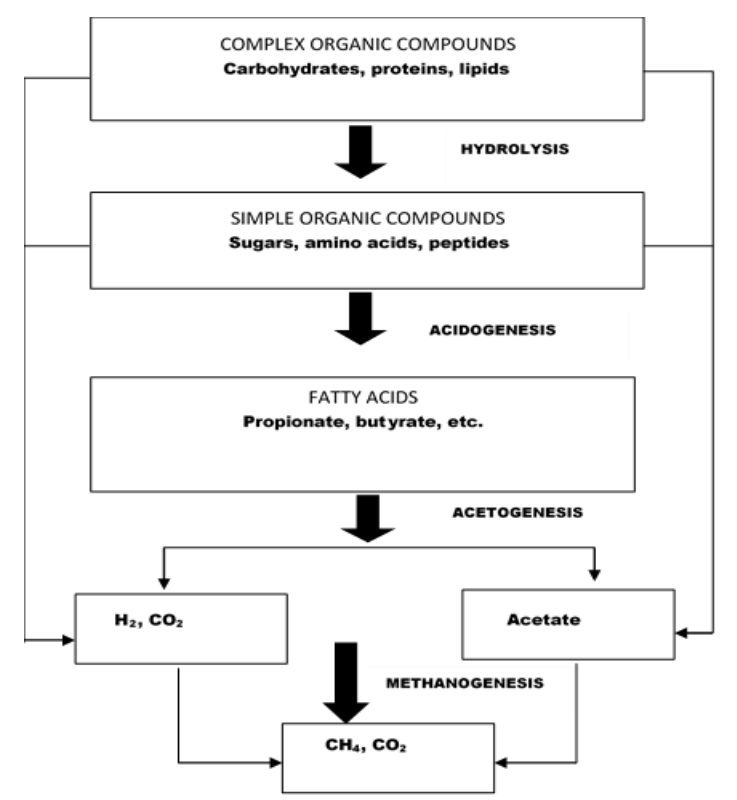

Figure 1. Stages for anaerobic digestion and formation of biogas

During the first stage, hydrolytic bacteria decompose complex organic matters into simple soluble organic molecules using water to split the chemical bonds between the substances. In the second stage, acidogenic or fermentative bacteria convert the small and simple molecules (monomers) resulted from the first stage 
(hydrolysis) to a mixture of volatile fatty acids (VFAs) such as acetic, propionic and butyric acids and other minor products like alcohols, hydrogen and carbon dioxide $\left(\mathrm{CO}_{2}\right)$. The third stage (acetogenesis) involves the formation of acetate through the reduction of the carbon dioxide $\left(\mathrm{CO}_{2}\right)$ or organic acids formed during the second stage by a group of anaerobic bacteria known as acetogens. However, the fourth and final stage (methanogenesis) involves the overall anaerobic conversion of organic matter to methane and $\mathrm{CO}_{2}$. This is achieved by the cleavage of two acetic acid molecules to generate methane and carbon dioxide, or by reduction of carbon dioxide with hydrogen by methane forming bacteria (methanogens).

The sludge in WSP and rumen contents in abattoirs are all biodegradables hence, could be used as feedstock for anaerobic digestion. However, the mono-digestion of abattoir wastes have been reported of creating technical challenges due to the inhibitory effects of ammonia and fatty acids on methanogens [9]. Besides, Mono-digestion of sewage sludge also have the limitation of low quantity of biogas production compared to the volume of feedstock added in a digester, as some of the organic matters in the sludge are already stabilized by the bacteria present [10]. In other words, the bacteria in sewage sludge are activated and would readily digest organic wastes more than those present in fresh rumen contents. Hence, co-digestion been the simultaneous anaerobic treatment of two or more biodegradables of different characteristics with the aim of enhancing biogas production, could be applied on these wastes (sewage sludge and rumen contents). Apart from improving the overall biogas production, the co-digestion of these wastes will reduce the cost of biogas production as both the sewage sludge and rumen contents can jointly be treated in a single installation or digester. Hence, it is important to investigate the biogas potentials of the said wastes when co-digested at different ratios in order to make necessary recommendations based on their performances.

\section{MATERIALS AND METHOD}

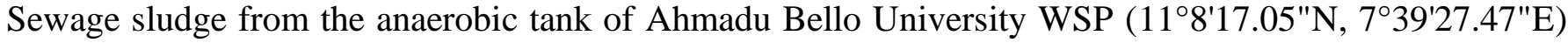

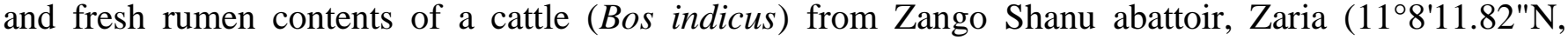
$\left.7^{\circ} 39 ' 59.88^{\prime \prime E}\right)$ were separately collected in a 5-liter container. The sludge and rumen contents were properly decanted in order to ensure that only the solid proportions are retained for the experiment. Sewage sludge to rumen contents (SS/RC) ratios of 1:0, 0:1, 1:1, 1:2 and 2:1 were prepared based on the total solids (TS) contents of the sludge and rumen contents, and were identified as A, B, C, D and E respectively. Since the both organic materials (sewage sludge and rumen contents) already contain anaerobic bacteria, additional bacteria were not introduced as inoculum into the various $\mathrm{SS} / \mathrm{RC}$ ratios prepared. The $\mathrm{SS} / \mathrm{RC}$ ratios 1:0 and 0:1 (i.e. A and B) were prepared for the sake of serving as controls in order to compare the results of the co-digestions with the mono-digestions of sewage sludge and rumen contents respectively. However, the exact quantities of sewage sludge and rumen contents used in preparing the various SS/RC ratios are given in Table 1.

Table 1. Proportions of feedstock components in digester

\begin{tabular}{ccccc}
\hline Assay ID & SS/RC ratio & $\begin{array}{c}\text { Sewage } \\
\text { sludge }(\mathrm{ml})\end{array}$ & $\begin{array}{c}\text { Rumen } \\
\text { contents }(\mathrm{ml})\end{array}$ & $\begin{array}{c}\text { volume of } \\
\text { feedstock }(\mathrm{ml})\end{array}$ \\
\hline A & $1: 0$ & 1000 & 0.0 & 1000 \\
B & $0: 1$ & 0.0 & 1000 & 1000 \\
C & $1: 1$ & 500 & 500 & 1000 \\
D & $1: 2$ & 333.3 & 666.6 & 1000 \\
E & $2: 1$ & 666.6 & 333.3 & 1000 \\
\hline
\end{tabular}


The various SS/RC ratios showed in Table 1 were measured into $2000 \mathrm{ml}$ conical flasks (digesters) using a graduated cylinder and were thoroughly mixed. Thereafter, samples were immediately obtained and analysed for concentrations of total solids (TS) added in the digesters using standard method [11]. The pH values of the mixtures were adjusted by adding few drops of $10 \mathrm{M} \mathrm{NaOH}$ solution to each mixture until the $\mathrm{pH}$ readings were between 6.5 and 7.8. Thereafter, the conical flasks were corked in order to maintain anaerobic (oxygen free) conditions and kept in a mesophilic environment $\left(30^{\circ} \mathrm{C}\right.$ to $\left.37^{\circ} \mathrm{C}\right)$ during retention period.

The daily quantity of biogas generated in the digesters were measured using the downward water displacement method. This was achieved by filling $1200 \mathrm{ml}$ beaker up to $90 \%$ capacity (1080ml) thereafter, $1200 \mathrm{ml}$ graduated cylinder fully filled with water was inverted and submerged below the water surface in the beaker, and clamped vertically by means of retort stand. A delivery tube was connected from the digester to the inverted graduated cylinder as shown in Figure 2. Thus, the biogas formed in the digester moved to the inverted graduated cylinder through the delivery tube. This consequently displaced corresponding volume of water from the inverted graduated cylinder to the beaker. Hence, the observed drop in water level in the graduated cylinder was recorded as the amount of biogas produced at the ambient temperature and pressure.

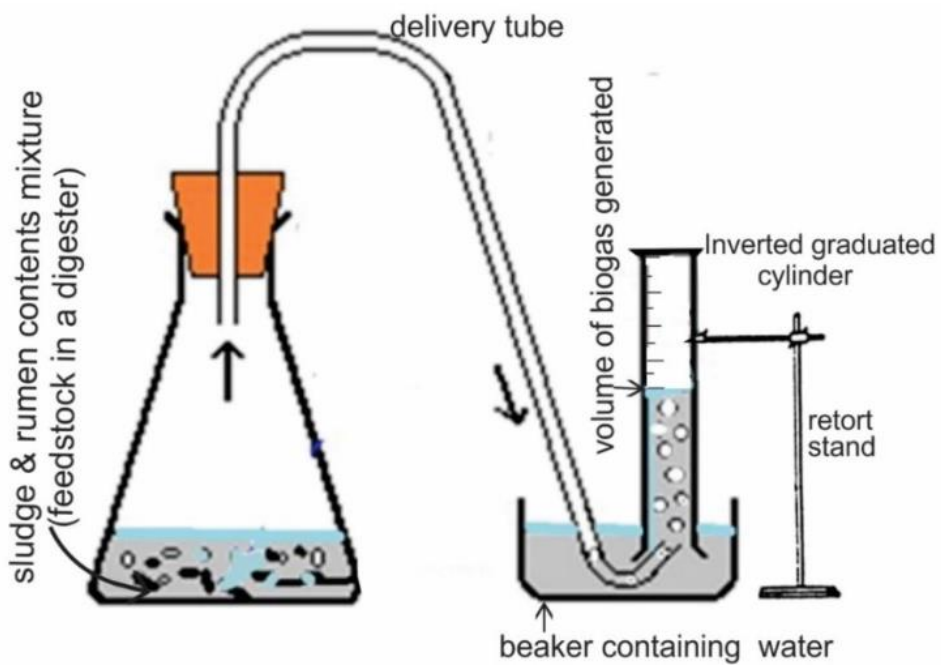

Figure 2. Determination of volume of biogas produced by water displacement method

The daily and cumulative biogas production for each experimental assay was recorded for a period of 75 days. Hence, the average daily biogas production was determined by dividing the cumulative biogas produced at the $75^{\text {th }}$ day by 75 . The result obtained was divided by the quantity (grams) of TS added in the digester thus, obtaining the daily biogas potential or yield in ml per gram of TS added. However, the quantity (grams) of TS added in each digester was known by multiplying the volume of feedstock in the digester $(1000 \mathrm{ml})$ by the concentration of TS.

\section{RESULTS AND DISCUSSION}

The concentrations of TS added in the digesters with SS/RC ratios 1:0, 0:1, 1:1, 1:2 and 2:1 are 2.38, 1.94, 2.16, 2.09 and $2.23 \mathrm{~g} / 1$ respectively while the results of the cumulative biogas production for the various experimental conditions (assays) are presented in Figure 3. The figure revealed that the cumulative biogas produced in the mono-digestion of sewage sludge (SS/RC ratio 1:0) during the first 25days (260ml) was higher than the mono-digestion of rumen contents (SS/RC ratio 0:1) which was $230 \mathrm{ml}$. This might be 
attributed to the fact that bacteria in the sewage sludge were already active in degrading organic matters in the WSP prior to the experiment while those in the rumen contents were still acclimatizing during the said period. Nevertheless, the reverse occurred for the remaining 50 days as the final cumulative volumes of biogas produced for SS/RC ratios 1:0 and 0:1 are 640 and $817 \mathrm{ml}$ respectively. This is because the quantity of degradable organic matters present in fresh rumen contents is usually higher than that of sewage sludge since the former often contain undigested ingesta (mostly grasses). Thus, explaining the reason why more biogas were produced in the mono-digestion of the rumen contents during the remaining 50 days compared to the mono-digestion of sewage sludge, after the bacteria in the sewage sludge have acclimatized. It is also revealed in Figure 3 that more quantities of biogas were produced in all the cases involving co-digestion (SS/RC ratios 1:1, 1:2 and 2:1) compared to the mono-digestions (1:0 and 0:1) which is in agreement with past related literatures [12-14]. However, the cumulative biogas produced in co-digestion with SS/RC ratios $1: 1,1: 2$ and $2: 1$ are 987,1045 and $968 \mathrm{ml}$ respectively.

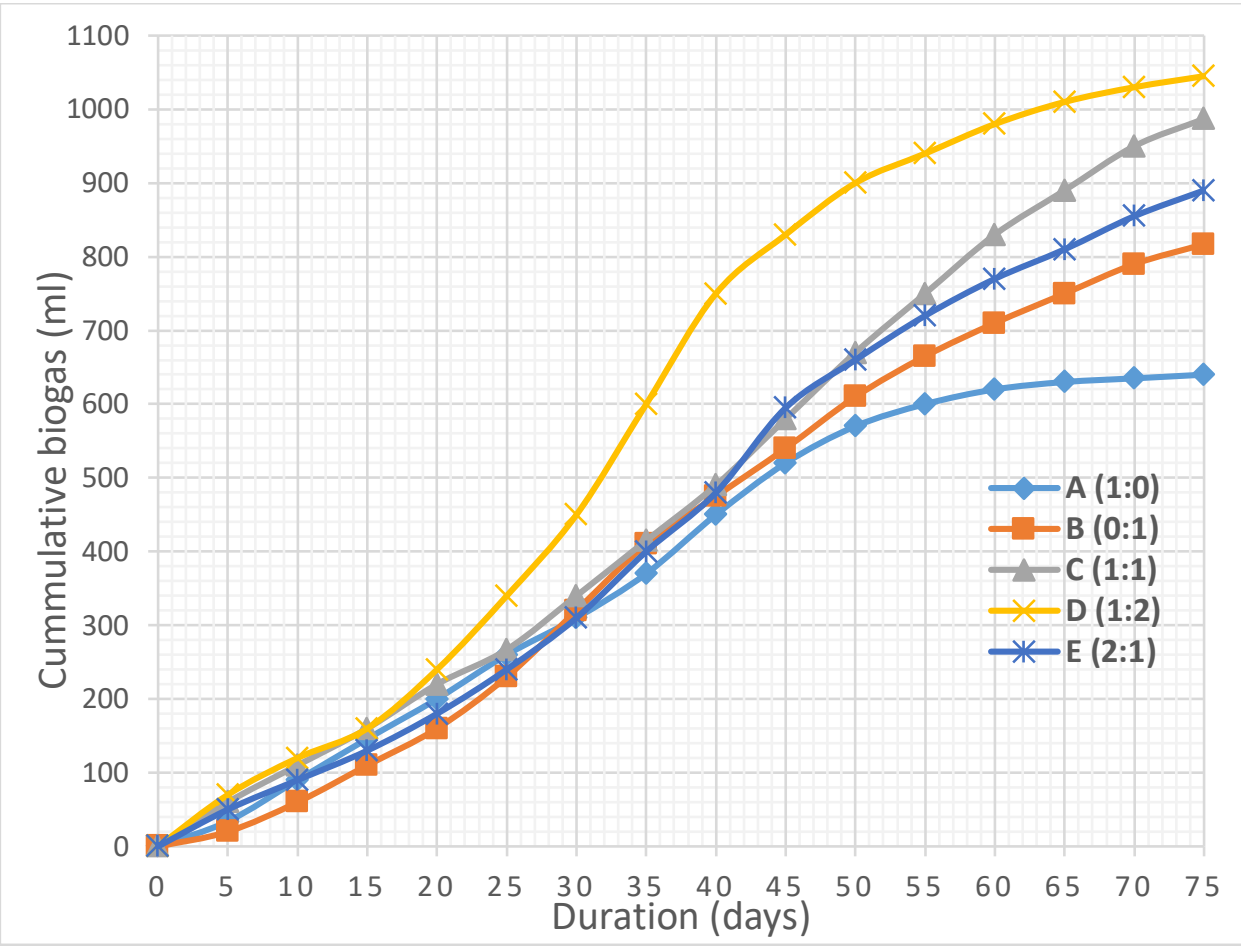

Figure 3. Cumulative biogas production

In other words, the biogas production in the co-digestions improved with an increase in rumen contents in the feedstock ( $\mathrm{SS} / \mathrm{RC}$ ratio). This might be due to the spike in activities of bacteria present in the rumen contents, caused by the already activated bacteria in the sewage sludge, which in turns degrade the numerous undigested organic matters usually present in rumen contents.

Based on the values obtained as concentrations of TS added in the digesters as well as the final cumulative volumes of biogas shown in Figure 3, the daily biogas potentials are calculated as shown in Table 2. 
Table 2. Biogas potential of various experimental assays

\begin{tabular}{|c|c|c|c|c|c|c|c|}
\hline $\begin{array}{c}\text { Assay } \\
\text { ID }\end{array}$ & $\begin{array}{c}\mathrm{SS} / \mathrm{RC} \\
\text { ratio }\end{array}$ & $\begin{array}{l}\text { Conc. of TS } \\
\text { added in } \mathrm{g} / \mathrm{l}\end{array}$ & $\begin{array}{l}\text { Volume } \\
\text { of } \\
\text { feedstock } \\
\text { in ml } \\
(d) \\
\end{array}$ & $\begin{array}{l}\text { Quantity of TS added } \\
\text { in grams }=\frac{(c) \times(d)}{1000} \\
(e)\end{array}$ & $\begin{array}{c}\text { Final cum. } \\
\text { biogas in } \mathrm{ml}\end{array}$ & $\begin{array}{c}\text { Average } \\
\text { daily biogas } \\
\text { in } \mathrm{ml}=\frac{(f)}{75} \\
(g)\end{array}$ & $\begin{array}{l}\text { Average daily biogas } \\
\text { potential in ml per } \\
\text { gram of TS added } \\
=\frac{(g)}{(e)}\end{array}$ \\
\hline A & $1: 0$ & 2.38 & 1000 & 2.38 & 640 & 8.53 & 3.59 \\
\hline B & $0: 1$ & 1.94 & 1000 & 1.94 & 817 & 10.89 & 5.61 \\
\hline $\mathrm{C}$ & $1: 1$ & 2.16 & 1000 & 2.16 & 987 & 13.16 & 6.09 \\
\hline D & $1: 2$ & 2.09 & 1000 & 2.09 & 1045 & 13.93 & 6.67 \\
\hline E & $2: 1$ & 2.23 & 1000 & 2.23 & 968 & 12.91 & 5.79 \\
\hline
\end{tabular}

Conc. $=$ concentration, cum. $=$ cumulative, $\mathrm{SS}=$ sewage sludge, $\mathrm{RC}=$ rumen contents, $\mathrm{TS}=$ total solids

(a), (b), (c), ......., (g) = column $1,2,3, \ldots \ldots \ldots, 7$ respectively.

It is clearly revealed in Table 2 that daily biogas potentials for mono-digestions of the sewage sludge (SS/RC 1:0) and rumen contents (SS/RC ratio 0:1) are 3.59 and $5.61 \mathrm{ml}$ per gram of TS added respectively. On the other hand, the values for co-digestions with SS/RC ratios 1:1, 1:2 and 2:1 are correspondingly 6.09, 6.67 and $5.79 \mathrm{ml}$ per gram of TS added. In other words, the highest daily biogas potential occurred when the SS/RC ratio is 1:2. Hence, biogas potential of the sewage sludge (SS) improved by 69.64, 85.79 and $61.28 \%$ when co-digested with rumen contents $(\mathrm{RC})$ at $\mathrm{SS} / \mathrm{RC}$ ratios 1:1, 1:2 and 2:1 respectively, while that of rumen contents (RC) improved by $8.56,18.89$ and $3.21 \%$ at SS/RC ratios 1:1, 1:2 and 2:1 respective.

\section{CONCLUSIONS}

Based on the analysed results acquired from this research, the following deductions are drawn:

i. $\quad$ Sewage sludge from ABU Waste Stabilization Pond and rumen contents from cattle (Bos indicus) have daily biogas potentials of 3.59 and $5.61 \mathrm{ml}$ per gram of TS added respectively when monodigested anaerobically without inoculum under mesophilic condition. However, more biogas are produced at the initial stage (first 25days of retention) for mono-digestion of the sewage sludge compared to rumen contents.

ii. Anaerobic co-digestion of the sewage sludge (SS) and rumen contents (RC) at SS/RC ratios 1:1, 1:2 and 2:1 produced more biogas compared to mono-digestions of equivalent volumes of SS and RC. Nevertheless, average daily biogas potential for SS/RC ratio 1:2 (6.67ml per gram of TS added) is the highest, followed by SS/RC ratio 1:1 (6.09ml per gram of TS added) and SS/RC ratio 2:1 $(5.79 \mathrm{ml}$ per gram of TS added).

iii. Biogas potential of the sewage sludge (SS) improved by $69.64,85.79$ and $61.28 \%$ when co-digested with rumen contents (RC) at SS/RC ratios $1: 1,1: 2$ and $2: 1$ respectively, while that of rumen contents improved by $8.56,18.89$ and $3.21 \%$ at $\mathrm{SS} / \mathrm{RC}$ ratios $1: 1,1: 2$ and $2: 1$ respective.

\section{ACKNOWLEDGEMENTS}

The encouragement role played by Mr Edjovigho Godswill Michael, during the period this article was written is highly appreciated. 


\section{REFERENCES}

1. Matthews, C., Crispie, F., Lewis, E., Reid, M., O'Toole, P. W., \& Cotter, P. D. (2019). The rumen microbiome: a crucial consideration when optimising milk and meat production and nitrogen utilisation efficiency. Gut microbes, 10(2), 115132.

2. Cammack, K. M., Austin, K. J., Lamberson, W. R., Conant, G. C., \& Cunningham, H. C. (2018). RUMINNAT NUTRITION SYMPOSIUM: Tiny but mighty: the role of the rumen microbes in livestock production. Journal of animal science, 96(2), 752-770.

3. Dayyani, N., Karkudi, K., \& Zakerian, A. (2013). Special rumen microbiology. International Journal of Advanced Biological and Biomedical Research, 1(11), 1397-1402.

4. Hasnisah, A., Azlina, A. A., \& Che, C. M. I. (2019). The impact of renewable energy consumption on carbon dioxide emissions: Empirical evidence from developing countries in Asia. International Journal of Energy Economics and Policy, 9(3), 135.

5. Gielen, D., Boshell, F., Saygin, D., Bazilian, M. D., Wagner, N., \& Gorini, R. (2019). The role of renewable energy in the global energy transformation. Energy Strategy Reviews, 24, 3850.

6. Arthur, R., Baidoo, M. F., \& Antwi, E. (2011). Biogas as a potential renewable energy source: A Ghanaian case study. Renewable Energy, 36(5), 1510-1516.

7. Balat, M., \& Balat, H. (2009). Biogas as a renewable energy source-a review. Energy Sources, Part A, 31(14), 1280-1293.

8. Demirbas, A., Taylan, O., \& Kaya, D. (2016). Biogas production from municipal sewage sludge (MSS). Energy Sources Part A Recovery Utilization and Environmental Effects, 38(20), 3027-3033.
9. Borowski, S., \& Kubacki, P. (2015). Codigestion of pig slaughterhouse waste with sewage sludge. Waste management, 40, 119-126.

10. Garg, S. K. (2012). Sewage disposal and air pollution engineering. Khanna Publsihers.

11. American Public Health Association, American Water Works Association, Water Pollution Control Federation, \& Water Environment Federation. (1915). Standard methods for the examination of water and wastewater (Vol. 2). American Public Health Association..

12. Almomani, F., \& Bhosale, R. (2020). Enhancing the production of biogas through anaerobic codigestion of agricultural waste and chemical pretreatments. Chemosphere, 126805.

13. Nkodi, M. T., Mulaji, K. C., Mabela, M. R., Kayembe, S. J., Biey, M. E., Ekoko, G., \& Taba, K. M. (2020). Investigation of Factors Affecting Biogas Production from Cassava Peels by Fractional Factorial Design Experimental Methodology. Journal of Applied Life Sciences International, 49-56.

14. Achinas, S., \& Euverink, G. J. W. (2019). Elevated biogas production from the anaerobic codigestion of farmhouse waste: Insight into the process performance and kinetics. Waste Management \& Research, 37(12), 1240-1249. 